San Jose State University

SJSU ScholarWorks

Master's Theses

Master's Theses and Graduate Research

Summer 2012

\title{
Differences and Similarities between Female Managers and Female Entrepreneurs
}

Maria Cespedes

San Jose State University

Follow this and additional works at: https://scholarworks.sjsu.edu/etd_theses

\section{Recommended Citation}

Cespedes, Maria, "Differences and Similarities between Female Managers and Female Entrepreneurs" (2012). Master's Theses. 4189.

DOI: https://doi.org/10.31979/etd.yyp3-ncf8

https://scholarworks.sjsu.edu/etd_theses/4189

This Thesis is brought to you for free and open access by the Master's Theses and Graduate Research at SJSU ScholarWorks. It has been accepted for inclusion in Master's Theses by an authorized administrator of SJSU ScholarWorks. For more information, please contact scholarworks@sjsu.edu. 
DIFFERENCES AND SIMILARITIES BETWEEN FEMALE MANAGERS AND FEMALE ENTREPRENEURS

\author{
A Thesis \\ Presented to \\ The Faculty of the Department of Psychology \\ San José State University \\ In Partial Fulfillment \\ of the Requirements for the Degree \\ Master of Science
}

by

Maria Jimena Céspedes

August 2012 
(C) 2012

Maria Jimena Céspedes

ALL RIGHTS RESERVED 
The Designated Thesis Committee Approves the Thesis Titled

DIFFERENCES AND SIMILARITIES BETWEEN FEMALE MANAGERS AND FEMALE ENTREPRENEURS

by

Maria Jimena Céspedes

APPROVED FOR THE DEPARTMENT OF PSYCHOLOGY

SAN JOSÉ STATE UNIVERSITY

August 2012

Dr. Megumi Hosoda

Dr. Howard Tokunaga

Dr. Joyce Osland
Department of Psychology

Department of Psychology

Department of Business 


\section{ABSTRACT \\ DIFFERENCES AND SIMILARITIES BETWEEN FEMALE MANAGERS AND FEMALE ENTREPRENEURS}

by Maria Jimena Céspedes

Although the number of female entrepreneurs has recently increased, there is little research that has compared female managers and female entrepreneurs in their work experiences and conditions. Therefore, the aim of this study was to examine the potential differences and similarities between women in management versus women in entrepreneurship regarding challenges, motivators for entry, adaptations, gender roles, and self-monitoring. Data collected from 87 women in management and entrepreneurship showed that female managers faced gender biases more than did entrepreneurs and had to choose between their professional and their personal goals when deciding to have children. Motivators for entry into entrepreneurship were increased job autonomy and flexibility of schedule. Regarding adaptations, all managers and entrepreneurs changed their communication style according to an audience and relied on their social support systems to deal with household responsibilities and on mentors for professional issues. Lastly, entrepreneurs were higher self-monitors and more likely to be androgynous than women in management. There were no differences in adoption of a masculine gender role between the two groups. Results of the present study indicate that these two groups of professional women have similar as well as different experiences and conditions. The implications of these findings are discussed. 


\section{ACKNOWLEDGEMENTS}

First and foremost, I would like to thank Dr. Megumi Hosoda for her vital and continuous support with this project. She went the extra mile and provided thorough and prompt feedback each time. Her insights and guidance were crucial throughout the development of my thesis and our conversations always inspired me to better myself. I would like to thank Dr. Howard Tokunaga for his straight forward approach and critiques that helped clarify my message. I also extend a special thanks to Dr. Joyce Osland for her help in the process of developing my thesis idea and the final revisions of my paper. I am grateful not only for the educational support I received from these and other faculty at SJSU, but also because they provided experiences that contributed to my professional growth and development. I also thank my fellow classmates for providing an inspiring and supportive environment in and outside the classroom. I will always treasure our friendships and hope we never grow apart.

Next, I would like to thank all the women who participated in my research. Although I used only personal contacts and networks to gather data, I was impressed with the amount of women who were willing to take their time to share their professional experiences with me. I hope I was able to bring visibility to women's current issues and provide something of value to them.

Last but not least, I would like to thank Daniel, my husband, for always supporting me and helping me keep true to myself and my goals. I could not have done without you! I thank my family and friends who believed in me every step of the way as well. I feel blessed to have such amazing people in my life! 


\section{TABLE OF CONTENTS}

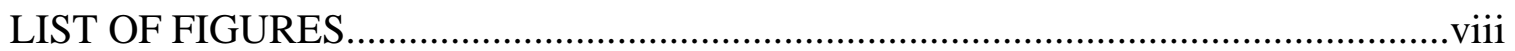

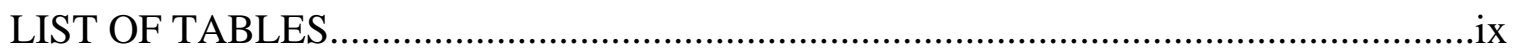

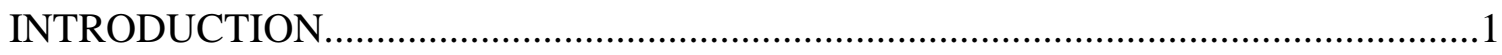

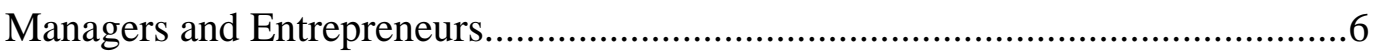

Female Managers versus Female Entrepreneurs...........................................8

Role Discrepancy in Female Leaders..............................................................11

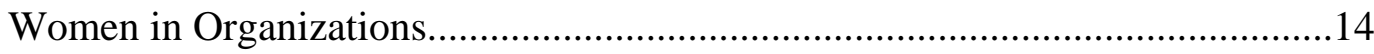

Women in Entrepreneurship.....................................................................16

Measuring Women’s Reactions to Situational Constraints................................17

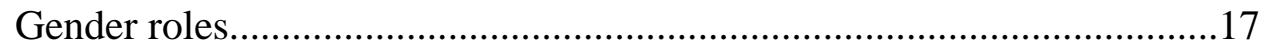

Self-monitoring...........................................................................20

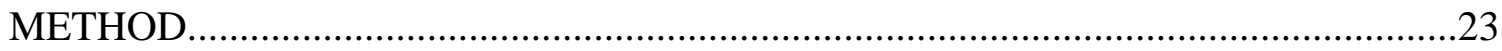

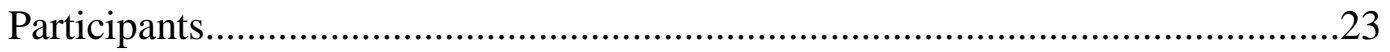

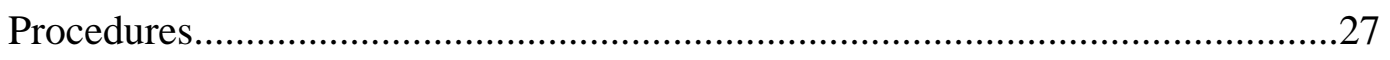

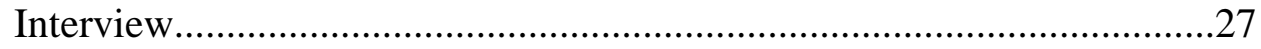

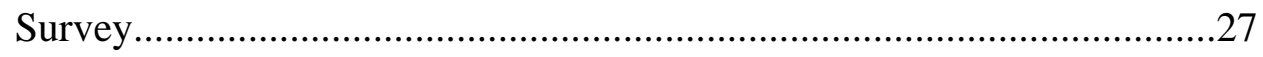

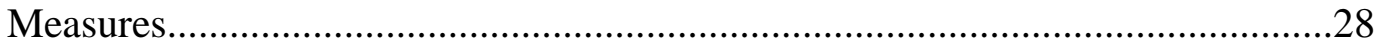

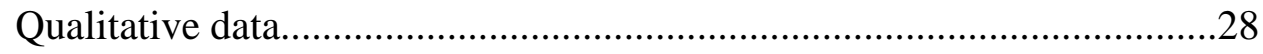

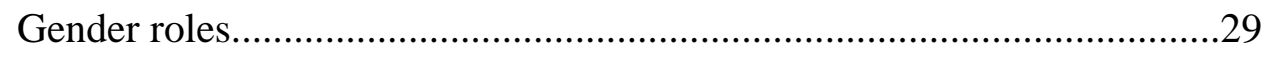

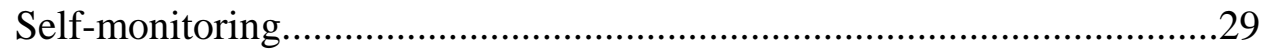

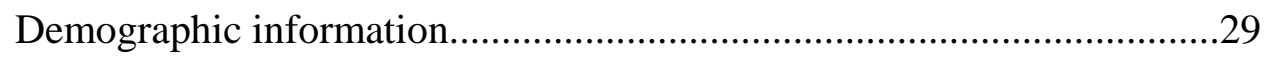




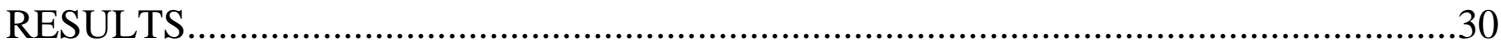

Qualitative Results and Research Question..........................................................30

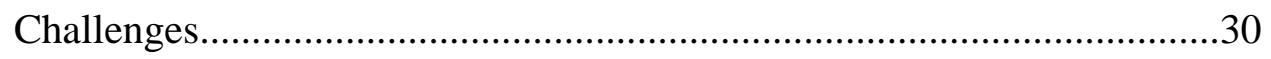

Motivators..............................................................................................31

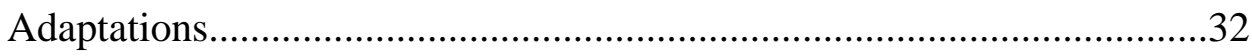

Descriptive Statistics and Test of Hypotheses......................................................35

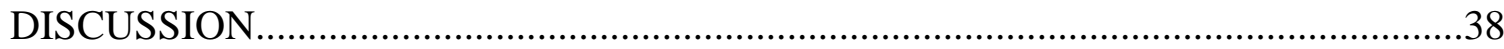

Strengths, Limitations, and Future Research.........................................................42

Practical Implications of the Present Study............................................................44

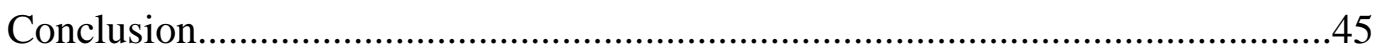

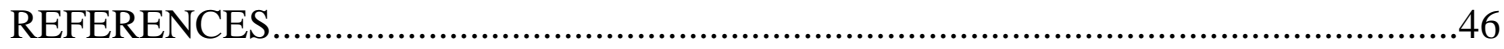




\section{LIST OF FIGURES}

Figure 1. Percentages of Employees and Entrepreneurs in Each Gender Role Categorization Using Median Split Data...................................................................37 


\section{LIST OF TABLES}

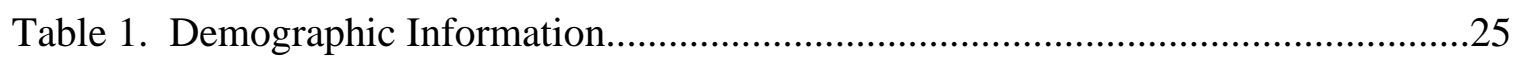

Table 2. Interview Questions and Responses by Managers and Entrepreneurs...............34

Table 3. Descriptive Statistics and $t$-tests for Gender Roles........................................35 


\section{Introduction}

In 2009, women represented $47 \%$ of the total working population in the United States (U.S.) and held 51\% of all positions in management, professional, and education (U.S. Bureau of Labor Statistics, 2010). Although these numbers are encouraging, according to a Catalyst (2010) report, women occupied only 2\% of the CEO positions and $15.2 \%$ of the executive officer positions in Fortune 500 organizations in 2009. At the same time, there has been a tremendous increase in the number of female-owned businesses in the U.S. In 2009, women owned $40 \%$ of all privately held businesses, a 17\% increase since 1997 and almost twice the growth rate of all businesses (Catalyst, 2011). The extent of the differences between the experiences of women in management and women in entrepreneurship and the factors that have influenced their rapid growth in entrepreneurship, however, are largely unknown.

Many researchers have examined potential differences and similarities between employees (i.e., mostly managers) and business-owners (i.e., entrepreneurs), but they have relied mainly on male samples (De Bruin, Brush, \& Welter, 2006). Studies show that there are differences between managers and entrepreneurs in some personality traits and motivators (Berthold \& Neumann, 2008; Stewart \& Roth, 2007). However, these findings may not be generalizable to female managers and female entrepreneurs because men and women have different values and work experiences and face different challenges. For example, entrepreneurs in general value autonomy, achievement, and implementation of ideas more than managers, but female entrepreneurs differ from their male counterparts in that the former value monetary success less and professional autonomy 
more (Orhan \& Scott, 2001; Orser \& Dyke, 2009; Powell \& Eddleston, 2008).

Additionally, women experience gender bias more often than men, especially in leadership positions (Daniel, 2004; Orhan \& Scott, 2001; Orser \& Dyke, 2009; Powell \& Eddleston, 2008; Stewart \& Roth, 2007). Our society expects men to behave in a masculine manner by exhibiting agentic traits and behaviors (e.g., being independent, assertive, and competent) and women to behave in a feminine manner by exhibiting communal traits and behaviors (e.g., being warm, unselfish, and emotionally expressive) (Karau \& Eagly, 1999). Yet, leaders are often expected to behave in a masculine manner regardless of sex or gender. Thus, if women are to pursue leadership positions, they are often disadvantaged especially when they behave in a feminine manner (Karau \& Eagly, 1999). Additionally, due to the historical male dominance of the management field and to gender bias, a glass ceiling exists. Glass ceiling is a term used for gender inequality and subtle discrimination in the organization. Women are the most frequent victims of glass-ceiling mentality in the workplace (Daniel, 2004).

Therefore, comparing managers and entrepreneurs tells only one side of the story because it masks potential gender differences. In order to better understand motivators, personality traits, and behavioral adaptations for both managers and entrepreneurs, we need to study men and women separately. Thus, there is a need for a study that compares female managers and female entrepreneurs. One might suspect that these two female groups share more similarities than differences; however, two different business settings (i.e., organizational and entrepreneurial) present unique challenges, pressures, and opportunities to the women in them that may result in different experiences and reactions 
to such experiences. For example, entrepreneurship is generally regarded as a more autonomous and flexible environment than are organizations (Heilman \& Chen, 2003; Powell \& Eddleston, 2008). Thus, female entrepreneurs may experience less organizational constraints than female managers. Additionally, some researchers suggest that female managers and entrepreneurs differ in their personality traits, motivators, and expectations as well (Brosdky, 1993; Orser \& Dyke, 2009; Winn, 2004).

Research findings show that women value and seek freedom in entrepreneurship (Heilman \& Chen, 2003; Powell \& Eddleston, 2008). In contrast, organizations have historically imposed often contradicting and rigid roles on female leaders (Kanter, 1977). When freed from organizational constraints, are female entrepreneurs more likely to adopt communal behaviors or agentic behaviors? This study attempts to answer questions like this. For the sake of consistency, in this study, the terms masculine and feminine will be used when referring to agentic and communal traits and behaviors.

Researchers (Anderson \& Thacker, 1985; Kanter, 1977) have suggested that impression management skills, such as self-monitoring, might be useful tools for women in out-of-role positions (e.g., women in non-traditional settings such as business management). Self-monitoring is a form of impression management that refers to the ability to self-observe and control one's expressive behavior based on situational cues picked from the environment (Snyder, 1974). Kanter (1977) argued that impression management skills might help women deal with the pressures of imposed gender stereotypes. Although research is far from conclusive, there is evidence that people can benefit from self-monitoring skills by adjusting their behavior to fit into different social 
expectations (Anderson \& Thacker, 1985; Becker, Ayman, \& Korabik, 2002; Dobbins, Long, Dedrick, \& Clemons, 1990; Riordan, Gross, \& Maloney, 1994). Women employed in organizations might engage in self-monitoring more often than female entrepreneurs because of greater behavioral constraints associated with the business setting; however, to the researcher's best knowledge, no research has yet examined this issue.

Women’s gender role might also change according to the workplace. Bem (1974) argued that masculinity and femininity were two independent dimensions that could be used to create three gender roles to characterize a person. As a result, people can be described as being feminine (possessing communal traits), masculine (possessing agentic traits), or androgynous (possessing a proportional mixture of both). Brodsky (1993) found that female entrepreneurs were more likely to adopt an androgynous role than were managers, who were instead more likely to adopt a masculine role. This difference in adopted gender roles might be attributed to fewer constraints in entrepreneurship than in business organizations regarding gender roles. Nevertheless, Daniel (2004) has challenged the extent of the freedom women in entrepreneurship are said to enjoy, arguing that it depends on the size of their businesses. Others have argued that it is a matter of different perspectives; that is, women see entrepreneurs as having masculine and feminine traits whereas men see entrepreneurs as having only masculine traits (Gupta, Turban, Wasti, \& Sikdar, 2009). Further research is needed to enhance our knowledge on this issue. 
In summary, gender biases seem to lure professional women into entrepreneurship because of working conditions that they perceive as more flexible and fair. However, the existence of such flexibility and freedom from bias is, in reality, greatly unknown given the lack of comparative research between female managers and entrepreneurs. Therefore, this study's purpose is two-fold: to expand the literature by investigating potential differences and similarities between the experiences of female managers and female entrepreneurs and to investigate the prevalence of different gender roles and selfmonitoring in each group. This study includes two parts: (a) a quantitative analysis of gender role and self-monitoring differences between women in organizations and women in entrepreneurship through a survey, and (b) a qualitative analysis of potential differences and similarities between these groups of women on challenges, motivators, and adaptations through interviews. It is important to note that although much research has investigated managers and entrepreneurs, there has been a lack of agreement on how to define managers and entrepreneurs per se (Collins, Hanges, \& Locke, 2004). Many studies have included samples with people working in organizations (i.e., not managers) and full-time students, whereas others have included self-employed people who owned business of different sizes. For the current study and given the available resources, women employed in organizations were compared with self-employed women. The following sections describe the literature more in depth and present the research question and the hypotheses that are tested. 


\section{Managers and Entrepreneurs}

In order to study women employed in organizations and self-employed women, it is essential to first review the literature on managers and entrepreneurs in general and to identify any differences and similarities already discovered between these groups. Research on management and entrepreneurship has mainly focused on studying male managers and entrepreneurs due to their greater availability and to societal and researchers' biases that regard them as representatives of managers and entrepreneurs (De Bruin et al., 2006).

There is much research on differences in motivation and personality traits between managers and entrepreneurs (Berthold \& Neumann, 2008; Stewart \& Roth, 2007). For example, Collins et al. (2004) conducted a meta-analysis investigating the relationship between a career choice and achievement motivation and found that entrepreneurs were significantly higher in achievement motivation than those who pursued other careers. This result was later supported by Stewart and Roth’s (2007) meta-analysis that showed that entrepreneurs scored significantly higher in achievement motivation compared to managers. Furthermore, Berthold and Neumann (2008) investigated managers and self-employed owners of German engineering firms and reported that an opportunity for self-fulfilling and implementation of own ideas were the motivators for entrepreneurship.

As mentioned earlier, research on managers and entrepreneurs is abundant, but there are several factors that prevent these findings from generalizing to female managers and entrepreneurs. Specifically, there are differences in challenges, motivators, and 
leadership traits between men and women that need to be taken into account when investigating similarities and differences between managers and entrepreneurs (e.g., Korabik, 1990; Melero, 2011; Orhan \& Scott, 2001; Orser \& Dyke, 2009; Powell \& Eddleston, 2008). For example, Kanter (1977) studied female employees in large firms in the 1970s and found that they endured isolation, encapsulation into rigid role stereotypes, and performance pressures due to their high visibility and contrast in a predominantly male-dominated workplace. She coined those women who reached higher ranks 'tokens' because they represented what women could accomplish, albeit being stripped of real power. These historically and socially derived challenges are unique to women in organizations and, although they seem to have subsided significantly in recent years, there is evidence of a glass ceiling that poses additional challenges to women who pursue managerial roles (Daniel, 2004; Heilman \& Chen, 2003). Glass ceiling is gender inequality in the form of, though usually subtle, discrimination that increases at higher ranks in the organization. For example, manifestations of gender inequality were reported in Eagly and Carli's (2007) study about married mothers who earned less and received fewer promotions than married fathers in spite of their having the same qualifications.

Apart from female managers experiencing the glass ceiling, men and women seem to differ in their motivators and leadership traits as well. According to Orser and Dyke (2009), there are gender differences in motivators for entrepreneurs. The researchers found that male entrepreneurs valued monetary success much more than their female counterparts, who valued other measures of success such as schedule flexibility, 
networks, and life quality (Orser \& Dyke). More importantly, Orser and Dyke found that "an increase in the perceived importance of success defined as professional autonomy was associated with a decreased likelihood of being employed in a corporate management position for females only” (p. 342). Powell and Eddleston (2008) found similar results. They argued that male and female entrepreneurs define success differently because they value different things. Female business owners value business success less than do male owners when success is defined by business and sales performance; therefore, their satisfaction is less related to those measures. Consequently, it is logical to assume that women and men are motivated to enter entrepreneurship by different reasons and should be studied separately. Regarding gender differences in leadership traits, using data from the 1998 Workplace Employment Relations Survey, Melero (2011) reported that compared to male managers, female managers had more interpersonal interactions with employees based on a greater monitoring of employee feedback and development.

In summary, male managers and entrepreneurs are different from female managers and entrepreneurs. Therefore, results based on predominately male samples should not be generalized to the female population and vice versa (De Bruin et al., 2006). Although few in number, studies on female managers and entrepreneurs are presented below.

\section{Female Managers versus Female Entrepreneurs}

Having established why it is important to expand the research on managers and entrepreneurs by separating females from males, it is important to establish why female managers should be compared to female entrepreneurs. On the one hand, there has been 
more research on female managers than on female entrepreneurs, especially regarding gender bias and gender role expectations. According to studies, female managers face a double-bind because they are expected to adhere to a masculine gender role in order to be successful, and at the same time they are penalized for violating feminine stereotypes (Becker et al., 2002; Eagly \& Carli, 2007; Heilman \& Okimoto, 2007; Karau \& Eagly, 1999; Vanderbroeck, 2010). On the other hand, although the concepts of greater freedom and autonomy have been mentioned to suggest a lower likelihood of gender bias in entrepreneurship, there is no conclusive evidence to support this assertion (Powell \& Eddleston, 2008). Research on female entrepreneurs is still in its infancy (De Bruin et al., 2006). Winn (2004) argued that people who entered entrepreneurship overestimated its degree of flexibility. Nevertheless, there might be gender role differences between female managers and female entrepreneurs due to greater organizational constraints on managers than on entrepreneurs, but only one study has so far attempted to investigate such differences.

Brodsky (1993) conducted a quantitative and qualitative study comparing gender roles of female managers and entrepreneurs. Although the sample was drawn from a national pool, most of the participants were from the East Coast and 95\% were Caucasian. Results showed that the groups shared many characteristics including "reject[ing] a stereotypically feminine sex role for themselves” (Brodsky, p. 369). However, managers took on a masculine role more often than entrepreneurs, whereas entrepreneurs adopted an androgynous role more often than managers. These differences were not statistically significant but they led to an interesting speculation. That is, fewer masculine roles 
among female entrepreneurs than among female managers support the notion of greater freedom in entrepreneurship regarding the expression of the self. This speculation warrants further investigation.

Apart from Brodsky (1993), there are no studies that directly compared female managers with female entrepreneurs. However, there is research on female managers only, on female entrepreneurs only, and on managers and entrepreneurs (both male and female) that investigated gender effects that suggest that there are differences between female managers and entrepreneurs. It has been shown that both male and female entrepreneurs value professional autonomy much more than do managers (Orser \& Dyke, 2009). Self-achievement, need for independence, and collecting the fruits from one's own ideas are the main motivators to entering entrepreneurship for women, whereas monetary success is a main motivator for men (Orhan \& Scott, 2001). Still, there is scant research on differences between female managers and female entrepreneurs, and although they may face many similar challenges (e.g., scarcity of role models), there are differences in situational constraints (e.g., glass ceiling) that might influence their behaviors differently.

Based on the above noted research findings and given that entrepreneurial roles may afford some women more freedom to pursue professional interests without many of the challenges arising from employment in large organizations (Orser \& Dyke, 2009), the following research question will be explored through interviews. 
Research question: What are differences and similarities between female managers and female entrepreneurs regarding challenges, motivators, and adaptations to a male-dominated business environment?

The following section reviews a literature on situational factors that affect professional business women and the impact such factors have on women's gender roles and behaviors. Specifically, research on women in leadership (in organizational and entrepreneurial settings) is reviewed in order to introduce the study's hypotheses regarding gender roles and self-monitoring.

\section{Role Discrepancy in Female Leaders}

Karau and Eagly (1999) have noted that there is a discrepancy between the female gender role that prescribes feminine behaviors for women and the stereotypical leader role that prescribes masculine behaviors for leaders. Furthermore, they have argued that society typically expects men to assume leadership roles, which puts women who pursue a leadership position in a double bind. Consequently, women face prejudices and barriers that ultimately affect their likelihood to emerge as leaders (Karau \& Eagly).

Gender bias occurs because gender is a very salient characteristic of people (Becker et al., 2002). Becker and colleagues investigated discrepancies in self-ratings of leader effectiveness and subordinate ratings of leader effectiveness. Results showed that such discrepancies were due to actors (i.e., managers) relying on different schemata than observers (i.e., subordinates). In the case of female managers, they focused on their managerial role because it was more salient to them, whereas their subordinates focused more on their managers' gender role because gender was more salient to them. 
Subordinates' use of their supervisors' gender in evaluating their effectiveness as leaders is consistent with Karau and Eagly's (1999) argument that women in business management are subject to gender bias.

More recently, Eagly and Karau (2002) developed the role congruity theory to explain why female leaders are in a double bind. According to this theory, gender roles are society's beliefs that describe ideal female and male behaviors (i.e., what men and women ought to be). These gender roles also prescribe agentic behaviors and traits for men (e.g., being assertive, ambitious, dominant, independent, self-sufficient, confident, and prone to act as a leader) and communal behaviors and traits for women (e.g., being affectionate, helpful, kind, sympathetic, nurturing, and gentle). Furthermore, role congruity theory states that perceived incongruity between roles leads to prejudice or bias. That is, leaders are typically defined in agentic terms which are consistent with masculine gender roles but conflict with feminine gender roles. Consequently, women who display agentic behaviors congruent with leadership roles are prone to violate feminine gender role expectations, whereas women who behave in communal ways tend to be seen as unsuited for leadership (Eagly \& Karau; Heilman \& Okimoto, 2007). Because of the perceived incongruity between leader roles and feminine gender roles, female leaders are often victims of prejudice and discrimination.

Eagly and Karau (2002) have further stated that factors that could influence the degree of prejudice and negative consequences against women are those that affect the magnitude of perceived incongruity between the two roles. For example, one factor is how leadership roles are construed. The more agentic leadership roles are defined, the 
greater the perceived incongruity between leader roles and feminine gender roles. This could explain the scarcity of female leaders in the military and political arenas. The perceiver's adherence to stereotypical gender roles and the characteristics of the target person are factors as well (Eagly and Karau). For example, those who rigidly adhere to traditional gender roles evaluate female managers more negatively than those who do not adhere to them. Thus, female managers with strong feminine characteristics such as pregnancy and feminine appearance would generate greater perceived incongruity. Sczesny, Spreemann, and Stahlberg's (2006) two experiments indirectly support Eagly and Karau’s (2002) proposition that leadership is seen as congruent with masculinity. Sczesny et al. found that individuals with typically masculine appearance were perceived as more competent leaders than individuals with typically feminine appearance, regardless of the sex of the target person. Only when perceivers were aware of their biases, was the influence of gender role stereotypes that negatively affected those with feminine characteristics diminished.

Furthermore, Ahl (2006) suggests that gender roles interact with and influence different business settings in a variety of degrees and manners. For example, women may face greater gender bias if they work in a traditionally masculine business such as construction than if they work in a traditionally feminine business such as childcare. Therefore, whenever women enter a work environment where roles are construed in masculine terms such as management, they find themselves in a double bind because of contradicting role expectations that result in barriers to their career advancement. The following sections discuss research on women in management and on women in 
entrepreneurship in depth in order to justify the need to compare them regarding gender roles and self-monitoring.

\section{Women in Organizations}

Research has shown that women face great difficulties in business because their historically prescribed gender role clashes with their role as leaders (Eagly \& Carli, 2007; Eagly \& Karau, 2002; Karau \& Eagly, 1999; Sczesny et al., 2006). Compared with men, women are less likely to emerge as a leader in a group (Karau \& Eagly, 1999), face greater discrepancies in their effectiveness ratings (Becker et al., 2002), and have to endure unrealistic performance pressures. In other words, women are expected to behave as leaders without violating feminine stereotypes (Kanter, 1977; Vanderbroeck, 2010).

Female managers are seen as out-of-role and an organizational setting often serves as a constraint to their advancement. Kanter (1977) found that women were made tokens (i.e., representatives of a particular sex or race in an otherwise homogeneous group) in an organization, which resulted in three outcomes for them. First, it gave tokens great visibility that weighted heavily on the expectations of their behavior. Second, the contrast of being the only woman in an all-male group led to the heightening of the dominant culture (i.e., masculine). Finally, the assimilation of the token in the group encapsulated her in a stereotyped role. Thus, tokenism prevented women from reaching upper management positions.

Nowadays, women are not so rare in the business world and have reached top executive positions in organizations (Baumgartner \& Schneider, 2010). However, they are still struggling to meet expectations from their superiors, peers, clients, and 
subordinates (Becker et al., 2002; Brodsky, 1993; Heilman \& Okimoto, 2007). Moreover, although people like to think that gender biases are disappearing and organizations are increasingly adopting fair policies, Castilla and Benard (2010) found that this might just be an illusion. In a series of experiments, they found that organizations that instituted merit-based practices were significantly more likely to favor men over equally qualified women when allocating bonuses. This difference did not occur in non-meritocratic organizations even after controlling for the gender of the person making bonus decisions. Castilla and Benard explained this by arguing that when individuals felt assured of their fairness (e.g., they work in a meritocratic organizations), they tended to relax and become unaware of their biases and therefore were prone to act on them. That is, when people do not think that they are vulnerable to a bias (i.e., they are certain of their fairness) and do not check for its potential influence, they unintentionally let it sway their actions.

Vanderbroeck (2010) maintains that female managers are never masculine enough and feminine enough to everyone's eyes and suggests that instead of women trying to imitate men, they should find their own leadership style. According to researchers, organizations should compensate by re-defining and diversifying leadership (Eagly \& Karau, 2002; Vanderbroeck). However, these are major changes that could take decades to occur. An alternative that many women seem to be favoring is starting a business of their own (Daniel, 2004), but what happens when they get there? Are self-employed women free from gender bias? The following section reviews the research on women in entrepreneurship. 


\section{Women in Entrepreneurship}

Research on female entrepreneurship is limited (Ahl, 2006; De Bruin et al., 2006). In general, empirical evidence suggests that entrepreneurship is also construed in masculine terms and entrepreneurs are expected to display masculine traits (Gupta et al., 2009). However, research on entrepreneurship has been criticized as being biased, narrowly focused, and based on samples predominantly composed of male participants (Ahl, 2006; De Bruin et al., 2006). Furthermore, female entrepreneurs tend to be disregarded as not serious or as less important than male entrepreneurs for the economy by the media and many researchers as well, which in itself is a result of gender bias (Bruni, Gherardi, \& Poggio, 2004; Heilman \& Chen, 2003). Fortunately, there has recently been a rise in research on female entrepreneurs that has attempted to investigate their perspectives and experiences directly.

Researchers have mostly investigated the reasons that women enter entrepreneurship and the challenges they encounter in such environment. Orhan and Scott (2001) discovered that, apart from situational factors (e.g., family succession, laid offs), women became entrepreneurs to fill their needs for self-achievement, be independent, and collect the fruits of their own ideas, many of which were harder to fulfill in organizations. Heilman and Chen (2003) have argued that more and more women are allured by entrepreneurship's promise of greater freedom and autonomy and a lower impact of gender biases. This argument has been supported by other researchers as well (e.g., Daniel, 2004; Powell \& Eddleston, 2008). Daniel (2004) claimed that glass ceiling issues pushed women out of organizations and into entrepreneurship and that as 
long as they kept their businesses small, women achieved the flexibility and freedom that they desired.

Gupta et al. (2009) studied the influence of gender role stereotypes on female entrepreneurs by surveying male and female students in the U.S., Turkey, and India. They asked participants to describe themselves and entrepreneurs in masculine or feminine terms. Results showed that entrepreneurship was predominantly stereotyped as masculine. However, these men and women differed in their definition of entrepreneurs. More specifically, men defined entrepreneurs mostly in masculine terms, whereas women defined entrepreneurs as possessing both masculine and feminine characteristics. That is, women defined entrepreneurship as possessing androgynous traits. Women might see entrepreneurship as one of the solutions to the glass ceiling, but little research attention has been paid to investigate the veracity of this belief.

\section{Measuring Women's Reactions to Situational Constraints}

Gender roles. Measures of women's reactions to the pressure to conform to certain gender roles could shed some light on the extent to which biased and conflicting performance expectations of women in organizations are different from those placed upon women in entrepreneurship. Baumgartner and Schneider (2010) interviewed women in management who had broken the glass ceiling and asked them how they had achieved it. These women’s strategies varied widely. For example, some emphasized assertiveness, whereas others emphasized aggressiveness. Still, some emphasized presentation styles, and others reported that they were detached from people's opinions and were tolerant to biased expectations. It seemed that there was no certain formula to 
overcome stereotypes and to succeed for female managers. However, these women used many strategies that were typically perceived as masculine such as being assertive, promoting oneself, being determined, inviting oneself to join the Old Boys network, and detaching oneself from the feminine stereotype. Furthermore, Bosak and Sczesny (2011) investigated whether perceptions of incongruity between women and leaders were malleable and found that, in fact, such incongruity could be reduced. A change in people’s perceptions about women as having masculine traits helped reduce incongruity between women and leaders, but not the other way around (i.e., the perceptions of leaders having feminine traits). These findings indeed suggest that for women to be successful in organizations, they need to appear as being more masculine.

Brodsky’s (1993) finding that female managers tended to adopt masculine roles more often than female entrepreneurs imply that there might be less gender bias in entrepreneurship for women. However, Lewis’ (2006) qualitative study indicated that female entrepreneurs could be in denial. Participants were female entrepreneurs who were members of an online networking group. Through content analysis of these women's online interactions and dialogues, Lewis found that many female entrepreneurs diminished their perceived differences from male entrepreneurs by suppressing, denying, or disapproving feminine behaviors in the group (e.g., talking about family issues). Lewis explained these women's reactions as being an effort to portray themselves as matching the entrepreneur stereotype; a stereotype that is based on masculine characteristics because its representative population has been largely male. Nevertheless, the lack of research comparing female managers and female entrepreneurs prevents one 
from conclusively identifying which career path poses greater performance pressures on women.

Based on her research, Korabik (1990) proposes that a mixture of masculine and feminine traits or an androgynous role might help women overcome gender bias and succeed in the business world. Isaac, Griffin, and Carnes' (2010) qualitative study supports Korabik's proposition. Isaac and colleagues investigated faculty members' opinions of three women chairs and found that a mixture of feminine and masculine characteristics in these leaders produced increased effectiveness ratings. It is important to notice that although these women occupied leadership positions, education is a setting where female employees are more abundant than are men employees (U. S. Bureau of Labor Statistics, 2009); therefore, these findings may not generalize to other industries. In summary, women adopt the behaviors and social roles that they believe yield the most benefits or help them avoid negative consequences in the setting where they work. Alternatively, women may choose professional paths that allow for a certain amount of freedom or that fit with their personalities or dominant traits. Additionally, organizations are the most frequently cited constraints (i.e., settings with standardized organizational norms and that are traditionally male dominated), whereas entrepreneurship is perceived as a more flexible setting. Given the findings that an adoption of masculine traits is still expected to be successful in organizations and that the adoption of a mixture of masculine and feminine traits is perceived by women as acceptable in entrepreneurship (Gupta et al., 2009), the following hypotheses will be tested in this study. 
Hypothesis 1: Women employed in organizations will report a greater adoption of a masculine gender role than self-employed women.

Hypothesis 2: Self-employed women will report a greater adoption of an androgynous gender role than women employed in organizations.

Self-monitoring. Apart from adopting a mixture of traditionally masculine and feminine behaviors, researchers have suggested that impression management skills could help women in management deal with conflicting performance pressures (Kanter, 1977). A form of impression management is self-monitoring, which was first coined by Snyder (1974) as the act of observing and controlling one's expressive behavior and presentation according to social appropriateness gauged by others' expressions. To illustrate, high self-monitors adjust their expressive behaviors to meet their audience's expectations and to enhance their personal image. Low self-monitors, however, project a more constant image even if their expressive behaviors conflict with an audience's expectations.

Anderson and Thacker (1985) studied the effects of self-monitoring on the assessments of applicants to computer sales positions. They found that although men's and women's self-monitoring and performance ratings were not significantly different, high self-monitoring (HSM) women received the highest performance ratings from interviewers. Researchers explained these findings by stating that, although women in computer sales positions were usually rare, self-monitoring helped them overcome biases by promoting a correct company image, facilitating their interactions within the company, and convincing customers that they were competent employees. Another study by Dobbins et al. (1990) examined gender and self-monitoring as factors influencing leader 
emergence. Results showed that men and those who were high self-monitors were more likely to emerge as leaders than were women and low self-monitors, respectively. Although these findings suggest that high self-monitoring is associated with positive outcomes, other research findings suggest that self-monitoring skills might negatively affect women in out-of-role positions (Riordan et al., 1994). Riordan and colleagues found that HSM women felt less effective than did HSM men at persuading an audience that they were cut-throat people, which was the study's task. However, researchers explained that this might have occurred because these women adopted a more self-protective presentation style compared to the men in order to lessen the costs of playing such an aggressive role.

Becker et al. (2002) argued that the negative consequences of self-monitoring on HSM women could be due to the conflicting perspectives that different perceivers had about women in out-of-role positions. Becker et al. had managers and their subordinates rate the managers' behaviors. Managers were rated according to what extent they showed initiating structure behaviors and consideration behaviors, which are comparable to masculine and feminine behaviors, respectively. Results showed that there were greater discrepancies in ratings of initiating structure behaviors between subordinates and their HSM female managers than between subordinates and their male managers, regardless of their self-monitoring levels or between subordinates and their low selfmonitor (LSM) female managers. That is, leader behaviors (i.e., initiating structure and consideration) performed by male managers were interpreted similarly by both the managers and their subordinates. However, initiating structure behaviors performed by 
female managers were interpreted differently depending on whether they were managers or subordinates when managers were HSM women (e.g., one side rated the manager high in initiating structure whereas the other rated her low). Unfortunately, Becker et al. did not report the direction of the discrepancies. The researchers attributed these discrepancies to HSM women being more aware of organizational norms (i.e., acting in a masculine way by exhibiting initiating structure behaviors) and their subordinates adhering to gender stereotypes.

As can be seen, research is inconclusive regarding the extent to which women use impression management skills and the degree of its effectiveness. However, given that organizations present heavier constraints to women and compel them to adjust their selfpresentation styles more than entrepreneurship, the following hypothesis will be tested.

Hypothesis 3: Women employed in organizations will score higher on selfmonitoring than women in entrepreneurship.

In summary, women's careers are limited by organizational constraints fueled by gender biases and discrimination (Davey, 2008; Karau \& Eagly, 1999; Orser \& Dyke, 2009). Women in organizations often face expectations of fulfilling two conflicting roles: women and leaders (Karau \& Eagly, 1999; Korabik, 1990). Entrepreneurship represents an alternative for women who see it as more flexible and less masculine than employment in organizations (Gupta et al., 2009; Heilman \& Chen, 2003; Orser \& Dyke, 2009; Powell \& Eddleston, 2008). Although research is limited and inconclusive, androgynous roles and self-monitoring skills have been suggested as remedies for the challenges faced by women in out-of-role positions (Anderson \& Thacker, 1985; Kanter, 1977; Korabik, 
1990). Hence, this study sought to expand Brodsky’s (1993) findings almost twenty years later by studying a different population sector (i.e., more ethnically diverse) and by adding self-monitoring.

\section{Method}

\section{Participants}

The sample consisted of 87 employees and entrepreneurs (51 employees and 36 entrepreneurs). The only criteria for inclusion in the study were that participants were female and working at the time of data collection. Table 1 presents demographic information for each group of women. As can be seen in the table, age distribution for the women employed in organizations was $24 \%$ in their 20 s, $20 \%$ in their 30 s, $32 \%$ in their 40 s, $20 \%$ in their 50s, and $4 \%$ in their 60s. Age distribution for the entrepreneurs was $14 \%$ in their 30 s, $30 \%$ in their 40 s, $36 \%$ in their 50 s, and $20 \%$ in their 60 s. There were no entrepreneurs in their 20s. Overall, in this sample the employees in organizations were noticeably younger than the entrepreneurs.

The ethnicity of the women for each group was predominately White. Seventy four percent of the entrepreneurs and 55\% of the employees were White American; the rest were Latin American, European, and Asian. There were no noticeable differences between the two groups in terms of their ethnic composition, except that employees were proportionally more diverse and included more Latin American women. Regarding marital status, most women in both groups were married (54\% of the employees and $67 \%$ of the entrepreneurs). However, there were more single employees than entrepreneurs 
( $28 \%$ versus $8 \%$ ), which could be explained by age differences between the two groups; women working in organizations tended to be younger than self-employed women. Data collected on family composition showed that $43 \%$ of the women in organizations had no children compared to $33 \%$ of the entrepreneurs, $12 \%$ of the employees and $19 \%$ of the entrepreneurs had one child, $39 \%$ of the employees and $28 \%$ of the entrepreneurs had two children, and only $6 \%$ of the employees but $19 \%$ of the entrepreneurs had three or more children.

Participants in this study were highly educated. Data showed that $96 \%$ of the women employed in organizations and $86 \%$ of the female entrepreneurs had a bachelor's degree and that more than half of all the women went to graduate school. Regarding employment status, $90 \%$ of the employees worked full-time, whereas only $64 \%$ of the entrepreneurs worked full-time. Additionally, $51 \%$ of the employees were managers. Employees worked in various industry sectors, with more concentration in the technology sector (40\%) followed by the education (17.5\%), health (12.5\%), and investment (12.5\%) sectors. Most of the entrepreneurs reported working in consulting (62.5\%) and professional services (12.5\%). The income distribution was relatively wide for both groups, ranging from less than $\$ 40,000$ to more than $\$ 200,000$. Almost half of employees (47\%) and one third of entrepreneurs made more than $\$ 100,000$ a year. 
Table 1

Demographic Information

\begin{tabular}{|c|c|c|}
\hline & Employees & Entrepreneurs \\
\hline \multicolumn{3}{|l|}{ Age range } \\
\hline $20-29$ & 12 (24\%) & \\
\hline $30-39$ & $10(20 \%)$ & $5(\overline{14} \%)$ \\
\hline $40-49$ & $16(32 \%)$ & $11(30 \%)$ \\
\hline $50-59$ & $10(20 \%)$ & $13(36 \%)$ \\
\hline $60-69$ & $2(4 \%)$ & $7(20 \%)$ \\
\hline \multicolumn{3}{|l|}{ Ethnicity } \\
\hline White American & $28(55 \%)$ & $26(74 \%)$ \\
\hline Latin American & $11(22 \%)$ & $3(8 \%)$ \\
\hline Asian & $4(8 \%)$ & $2(6 \%)$ \\
\hline European & $5(10 \%)$ & $4(11 \%)$ \\
\hline Other & $3(6 \%)$ & - \\
\hline \multicolumn{3}{|l|}{ Marital status } \\
\hline Married & 27 (54\%) & $24(67 \%)$ \\
\hline Separated & $1(2 \%)$ & $1(3 \%)$ \\
\hline Divorced & $4(8 \%)$ & $3(8 \%)$ \\
\hline Living with Partner & $3(6 \%)$ & $4(11 \%)$ \\
\hline Widowed & $1(2 \%)$ & $1(3 \%)$ \\
\hline Single & $14(28 \%)$ & $3(8 \%)$ \\
\hline \multicolumn{3}{|l|}{ Children } \\
\hline 0 & 22 (43\%) & $12(33 \%)$ \\
\hline 1 & $6(12 \%)$ & $7(19 \%)$ \\
\hline 2 & $20(39 \%)$ & $10(28 \%)$ \\
\hline 3 & $3(6 \%)$ & $4(11 \%)$ \\
\hline 4 & - & $3(8 \%)$ \\
\hline \multicolumn{3}{|l|}{ Education level } \\
\hline Some College & $2(4 \%)$ & $5(14 \%)$ \\
\hline Bachelor's Degree & $21(42 \%)$ & $11(31 \%)$ \\
\hline Graduate School & $27(54 \%)$ & $20(55 \%)$ \\
\hline
\end{tabular}


Table 1

Demographic Information (continued)

\begin{tabular}{lcc}
\hline & Employees & Entrepreneurs \\
\hline Employment status & & \\
Full-time & $46(90 \%)$ & $23(64 \%)$ \\
Part-time & $5(10 \%)$ & $13(36 \%)$ \\
Industry & & \\
Technology & $16(40 \%)$ & $3(9.4 \%)$ \\
Education & $7(17.5 \%)$ & $2(3.6 \%)$ \\
Health & $5(12.5 \%)$ & $2(3.6 \%)$ \\
Investment & $5(12.5 \%)$ & $20(62.5 \%)$ \\
Consulting & $3(7.5 \%)$ & $4(12.5 \%)$ \\
Services & $2(5 \%)$ & \\
& & $4(11 \%)$ \\
Income range & $3(6 \%)$ & $2(6 \%)$ \\
Less than 40,000 & $11(23 \%)$ & $7(20 \%)$ \\
40,000 to 60,000 & $7(14 \%)$ & $10(29 \%)$ \\
60,001 to 80,000 & $5(10 \%)$ & $3(8.5 \%)$ \\
80,0001 to 100,000 & $12(25 \%)$ & $3(8.5 \%)$ \\
100,001 to 150,000 & $8(16 \%)$ & $6(17 \%)$ \\
150,001 to 200,000 & $3(6 \%)$ & \\
More than 200,000 & &
\end{tabular}




\section{Procedure}

This study contained two methods of data collection in order to better understand potential differences and similarities between women employed in organizations and selfemployed women; qualitative (interview) and quantitative (survey).

Interview. Participants for the study were reached through the researcher's personal network followed by snowball sampling. Six participants agreed to be interviewed for collection of information regarding challenges, motivators, and adaptations to their work environment. Participants were three middle and top managers employed in different organizations and three self-employed women who owned small to medium sized businesses. Interviews were semi-structured and conducted at their convenience. Participants were all asked the same ten questions; however, other topics were also explored if a participant introduced them. Interviews were audio-taped and lasted for an average of 30 minutes each. Participants had the choice of being interviewed in person or by phone. Those who were interviewed in person received two copies of a consent form signed by the researcher. They read them and kept one for their

records. Participants who were interviewed by phone received the consent form by email stipulating that their participation in the interview indicated their consent. At the beginning of the phone interview, participants were asked if they read, understood, and agreed to the consent form. Interview content was later transcribed by the researcher for content analysis and only anonymous quotes were reported.

Survey. Participants received an invitation email with a consent form and web links to the survey (i.e., one to be completed by employees and another for female 
entrepreneurs). At that time, they read an agreement to participate in research and chose whether or not to participate in the survey. If they chose to participate, they clicked the survey link (surveymethods.com) that took them directly to the first page of the anonymous survey. The survey took approximately 12 minutes to complete. Completion of the survey concluded their participation in the study except for those who agreed to be interviewed as well. In the survey, participants filled out items that measured gender role, self-monitoring, and demographic information.

\section{Measures}

Qualitative data. Because research on female managers and entrepreneurs is still relatively new, many studies have used and encouraged qualitative research to understand the complex and sensitive topic of women’s experiences in business settings (e.g., Brodsky, 1993; Orhan \& Scott, 2001; Winn, 2004). This is because a qualitative study allows for a more in-depth investigation of individuals' experiences that cannot be obtained from a quantitative study (Nichols-Casebolt \& Spakes, 1995). This study’s semi-structured interviews consisted of 10 open-ended questions developed by the researcher regarding aspects of participants’ work experience (i.e., background information, challenges, motivators, and adaptations). Sample questions are "What are

the easiest and the most difficult parts of your job?," "How do you cope with and adapt to professional challenges?” and “As an entrepreneur or manager, what is different because you are a woman?” Participants were also allowed to express themselves and elaborate their responses in any direction that they chose. 
Gender roles. Gender roles were measured using a modified version of the short Bem Sex Role Inventory (BSRI) (Colley, Mulhern, Maltby, \& Wood, 2009). For this study, only 20 items that measured femininity and masculinity were used but the 10 items used to measure social desirability were not included. Responses were given on a 7-point Likert scale ranging from 1 (Never true) to 7 (Always true). A Cronbach alpha for the masculinity subscale is .83 and for the femininity subscale is .87 . Examples of the items measuring masculinity are "Aggressive," and "Independent.” Examples of the items measuring femininity are “Affectionate," and “Tender.” Higher scores indicate higher levels of masculinity and femininity.

Self-monitoring. Self-monitoring was measured using a short version of the Self-Monitoring Scale (Snyder, 1974). The scale had 13 items measuring sensitivity to the expressive behavior of others and the ability to modify self-presentation (Lennox \& Wolfe, 1984). Responses were given on a 5-point Likert scale ranging from 1 (Strongly disagree) to 5 (Strongly agree). A Cronbach alpha for the short Self-Monitoring Scale is .86 for the present sample. Examples of items are "In social situations, I have the ability to alter my behavior if I feel that something else is called for" and "I am often able to read people’s true emotions correctly through their eyes.” Higher scores on this scale indicate higher levels of self-monitoring.

Demographic information. Participants were asked to report their age range, ethnicity, marital status, number of children, level of educational attainment, employment status (full- or part-time), job industry, and income range. 


\section{Results}

\section{Qualitative Results and Research Question}

The research question asked whether there would be differences between female managers and female entrepreneurs regarding challenges, motivators, and adaptations to a male-dominated business environment. This question was explored using content analysis of interview responses from three managers and three entrepreneurs. The interviews consisted of ten questions, four for background information, and six about challenges, motivators, and adaptations. A summary of interview responses is displayed in Table 2.

Challenges. Dealing with different expectations, flexibility of schedules, gender stereotypes, as well as prioritizing family and professional responsibilities and goals were mentioned as challenges by the managers. For example, a senior executive at a mediumsize firm (Manager \#2) said that the hardest part of her job was “Dealing with managers” expectations and delivering to those expectations on a regular basis. As a woman you have to fight stereotypes that may exist in some people's minds. Their first impression is to put you in a category. Some people take information from men but not from women and you can’t over-react.” However, she later added “But also I find my gender helpful, it can work both ways.” Her response shows that gender stereotypes still affect women in organizations.

Although the managers interviewed had some flexibility to set their own schedules, this often meant they were expected to work long hours or be available after office hours and on weekends. "When things are going wrong, you have to be available,” 
said Manager \#1. Regarding prioritization of goals, female managers sometimes had to choose between growing professionally and raising a family. Manager \#1 said that when she decided to have children she had to "slow down [her] career." Unfortunately, having a baby meant that her career advancement was delayed.

Commonly reported challenges by the entrepreneurs were taking on financial risk, keeping work-life balance, and developing a business. Interestingly, gender stereotypes were not mentioned as a challenge. These female entrepreneurs mentioned common aspects of developing a business as challenges, such as finding competent employees, financing their businesses, and managing risk. When asked what was different in business for women, all three entrepreneurs answered that not much. They did not feel that gender bias was particularly a concern for them. Furthermore, although they struggled to maintain a work-life balance and relied heavily on their family for help with childcare, they did not see it as only a women’s issue, as Entrepreneur \#3 said “...worklife balance is difficult for everyone these days."

Motivators. Managers were passionate about their jobs and valued the monetary rewards. For example, Manager \#1 said she wanted to work in an organization to “...feel part of a team." Manager \#3 said she entered and stayed in management because of the money she earned. No other motivators for entry into management were mentioned. However, between management and entrepreneurship, management is a more typical choice; all entrepreneurs who were interviewed had previously worked as employees. They moved to entrepreneurship either because they could not find satisfaction working for organizations or by accident such as having the opportunity to buy the business where 
they worked. Entrepreneur \#3 stated "I wanted to control my own destiny and run an organization the way I thought it should be run.” In addition, a desire for achievement, increased job autonomy, and the ability to set their own schedules were motivators to enter entrepreneurship.

Adaptations. All interviewees, managers and entrepreneurs, mentioned that they changed their communication style constantly according to an audience. For example, Manager \#1 said "It is very different when you talk to your partners, clients, team members, managers, and peers. You may have the same message but you have to adapt to your audience. Great communicators would do that. Your message has to be consistent but adapt to your audience.” Entrepreneur \# 3 stated that "I try to modify my appearance, behavior, and style based on my audience” and Entrepreneur \#2 said that "there are a lot of different communication styles that I use.” Another shared adaptation was relying on mentors and family. Both managers and entrepreneurs reported having mentors for different aspects of their careers and the help of family and friends for managing household responsibilities. Only managers, however, occasionally postponed professional goals in favor of childbearing.

In summary, results of the interviews showed that female entrepreneurs had an easier time dealing with gender stereotypes and setting their own schedules than managers did. Responses from the managers clearly showed that gender bias was a main challenge to them. They felt the need to continuously manage conflicting expectations and sometimes fight against gender stereotypes as well. Female entrepreneurs emphasized the need for social support and delegating responsibilities in order to succeed, 
such as having family members help with childcare. Managers had to make great effort in order to keep a work-life balance and share household responsibilities with their partners as well. They even felt that they had to delay professional goals if they wanted their offspring. Results showed that women in organizations and self-employed women faced different challenges (e.g., gender bias for managers and managing risk for entrepreneurs) and were motivated by different aspects of their professional environments (e.g., autonomy for entrepreneurs and monetary rewards for managers). Both groups developed similar adaptations; that is, changing their communication style constantly according to an audience and relying on mentors and family. However, only female managers reported having to choose between personal and professional goals. Overall, female managers and entrepreneurs faced and adapted to challenges related to working outside the home while raising a family, but they also developed adaptations to challenges specific to management or entrepreneurship and were motivated by different objectives. 
Table 2

Interview Questions and Responses by Managers and Entrepreneurs

\begin{tabular}{|c|c|c|}
\hline Themes and Questions & Managers & Entrepreneurs \\
\hline $\begin{array}{l}\text { Challenges } \\
\text { "What is the most difficult } \\
\text { part of your professional } \\
\text { role? And "Is anything } \\
\text { different because you are a } \\
\text { woman?" }\end{array}$ & $\begin{array}{l}\text { • "(An) IT challenge is that it is a 24-hour job. } \\
\text { When things are going wrong you have to be available” } \\
\text { - "Dealing with managers' expectations and } \\
\text { delivering to those expectations on a regular basis. As a } \\
\text { woman you have to fight stereotypes that may exist in } \\
\text { some people’s minds" } \\
\text { • "It is culturally expected for women to put } \\
\text { family responsibilities first" } \\
\text { - "I did have to make the conscious decision to } \\
\text { slow down my career when I decided to have kids. } \\
\text { When I had my first kid, I got stuck in a certain role and } \\
\text { when (she) turned five I moved on" }\end{array}$ & $\begin{array}{l}\text { • "The hardest is the risk, there is a lot of } \\
\text { risk" "The hardest part is finding good } \\
\text { e "Thloyees and finding capital to grow the } \\
\text { emsiness" } \\
\text { - "I think work/life balance is difficult for } \\
\text { everyone these days" }\end{array}$ \\
\hline $\begin{array}{l}\text { Motivators } \\
\text { "Why did you choose } \\
\text { management or } \\
\text { entrepreneurship?” And } \\
\text { "What is the easiest part of } \\
\text { your job?” }\end{array}$ & $\begin{array}{l}\text { - "I really wanted to work with people... I needed } \\
\text { to feel part of a team" } \\
\text { "I love coaching and managing a team" } \\
\text { "The easiest is telling your story to customers } \\
\text { about why they should partner with you" } \\
\text { - "I chose it for the money" }\end{array}$ & $\begin{array}{l}\text { - "The easiest part of being self-employed is } \\
\text { setting my own schedule" } \\
\text { - "I wanted to control my own destiny and } \\
\text { run an organization the way I thought it should be } \\
\text { run" }\end{array}$ \\
\hline $\begin{array}{l}\text { Adaptations } \\
\text { "How do you cope with } \\
\text { professional challenges? And } \\
\text { "Does your communication } \\
\text { style change according to } \\
\text { your audience?" }\end{array}$ & $\begin{array}{l}\text { - "It is very different when you talk to your } \\
\text { partners, clients, team members, managers, peers. You } \\
\text { may have the same message but you have to adapt to } \\
\text { your audience" } \\
\text { - "Mentors help, I have a mentor for everything" }\end{array}$ & $\begin{array}{l}\text { - "There are a lot of different } \\
\text { communication styles that I use" } \\
\text { - "I try to modify my appearance, behavior } \\
\text { and style based on my audience" } \\
\text { - "Have a complementary relationship with } \\
\text { my partner" } \\
\text { - "Everybody around me, whether they are } \\
\text { my friends, my family, my coworkers they are all } \\
\text { used to getting projects from me now. I find it is } \\
\text { much easier to delegate that to try to get } \\
\text { everything..." } \\
\text { - "Used a mentor" }\end{array}$ \\
\hline
\end{tabular}




\section{Descriptive Statistics and Test of Hypotheses}

Table 3 presents the descriptive statistics and results of $t$-tests for gender roles for female employees and entrepreneurs. Scores for masculinity and femininity were computed directly from the two subscales of the BSRI. Scores for androgyny were computed using Kalin’s (1979) formula where Androgyny $=[(\mathrm{M}+\mathrm{F})-(|\mathrm{M}-\mathrm{F}|)] / 2$, as functions of a participant's masculinity (M) and femininity (F) scores. A closer look at Table 3 shows that entrepreneurs had higher scores on masculinity, femininity, and androgyny than employees.

Table 3

Descriptive Statistics and t-tests for Gender Roles

\begin{tabular}{lccc}
\hline & $\begin{array}{c}\text { Employees } \\
(n=51)\end{array}$ & $\begin{array}{c}\text { Entrepreneurs } \\
(n=36)\end{array}$ & \\
\hline BSRI & $\mathrm{M}(\mathrm{SD})$ & $\mathrm{M}(\mathrm{SD})$ & $t$-test \\
Masculinity & $4.79(.82)$ & $5.04(.68)$ & $-1.48, p=.14$ \\
Femininity & $5.35(.87)$ & $5.54(.78)$ & $-1.05, p=.30$ \\
Androgyny & $4.52(.76)$ & $4.86(.74)$ & $-2.09, p=.04^{*}$ \\
\hline
\end{tabular}

Note: $* p<.05$

Hypothesis 1 stated that women employed in organizations would report a greater adoption of a masculine gender role than self-employed women. This hypothesis was tested using a $t$-test with a Type I error rate of .05. Results showed that the difference between managers $(M=4.79)$ and entrepreneurs $(M=5.04)$ on masculinity was not statistically significant, $t(85)=-1.48, p=.14$. Thus, Hypothesis 1 was not supported. 
Hypothesis 2 stated that self-employed women would report a greater adoption of an androgynous gender role than women employed in organizations. This hypothesis was tested using a $t$-test with a Type I error rate of .05 . Results showed that there was a significant difference between the two groups in which entrepreneurs $(M=4.86)$ scored significantly higher in androgyny than managers $(M=4.52), t(85)=-2.09, p<.05$.

Additionally, masculinity and femininity scores were median split to create four categories of gender roles (Undifferentiated, Masculine, Feminine, and Androgynous). The median split is recommended by Lenney (1991) because it allows differentiating people who score high-high on both the masculinity and femininity subscales (androgynous) from those who score low-low on both scales (undifferentiated). Scores were median split at 5.7 for the femininity variable and 5 for the masculinity variable. Figure 1 presents a proportion in each gender role category for the female employees and the female entrepreneurs. A closer look at Figure 1 shows marked differences in gender role classification between the two groups such that entrepreneurs were predominately androgynous or masculine whereas employees adopted all four gender roles comparatively. However, the chi-square test results showed that such differences were not statistically significant, $\chi^{2}(3)=4.18, p=.24$. Hypothesis 2 was supported using a continuous method of analysis ( $t$-test) but it was not supported using a non-parametric statistic (chi-square test). 


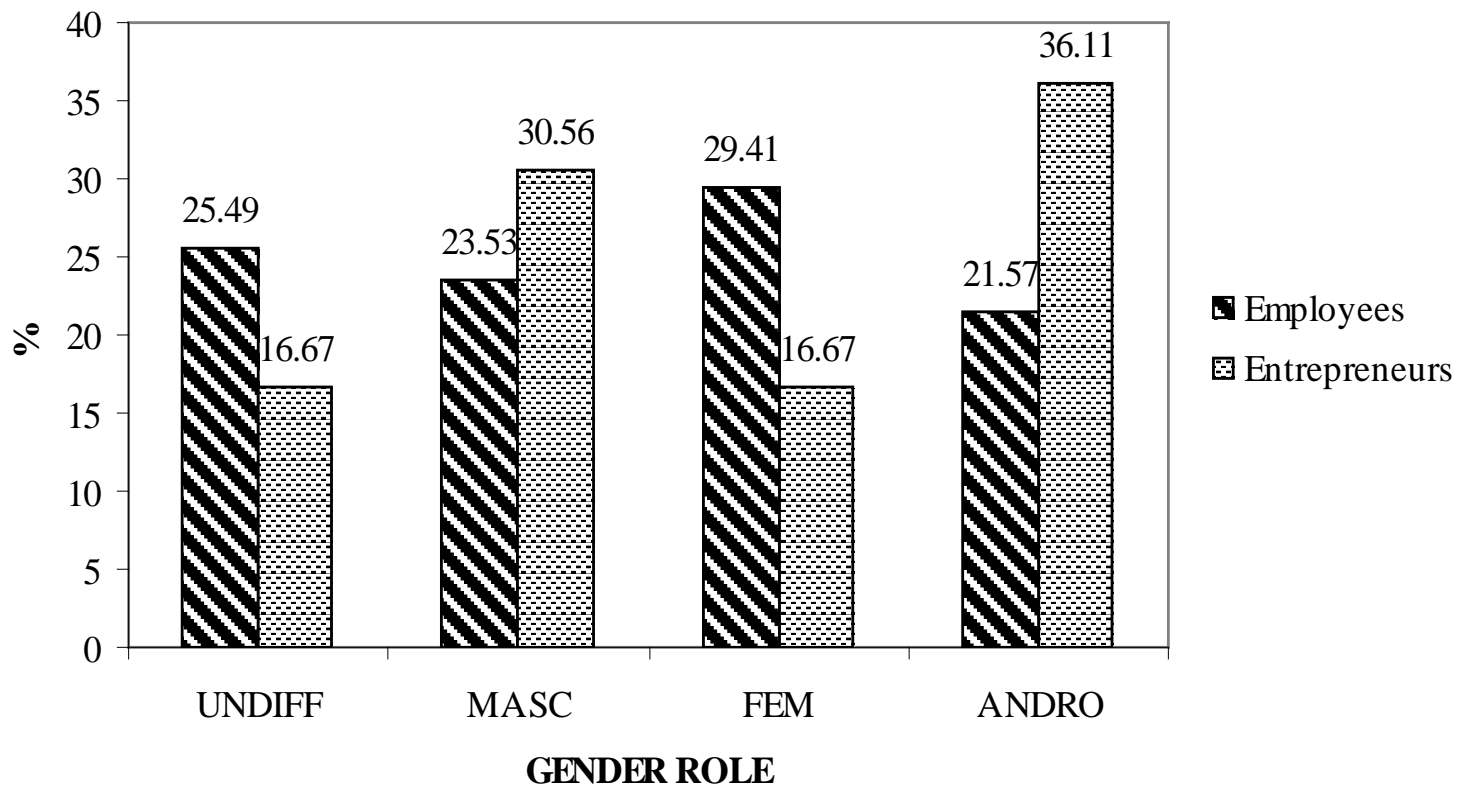

Figure 1. Percentages of Employees and Entrepreneurs in Each Gender Role Categorization Using Median Split Data. UNDIFF = undifferentiated gender role; MASC = masculine gender role; FEM = feminine gender role; ANDRO = androgynous gender role .

Hypothesis 3 stated that women employed in organizations would score higher on self-monitoring than women in entrepreneurship. This hypothesis was tested using a $t$ test with a Type I error rate of .05 . Results showed that entrepreneurs $(M=4.08, S D$ $=.52)$ were higher on self-monitoring than employees $(M=3.82, S D=.43)$ and that this difference was statistically significant, $t(85)=-2.55, p<.05$. However, the direction of the difference was the opposite of what was expected in the hypothesis. Thus, Hypothesis 3 was not supported. 


\section{Discussion}

Research on management and entrepreneurship relies heavily on studies of male managers and entrepreneurs and leaves women's professional conditions largely unclear and under-studied, particularly those of female entrepreneurs (De Bruin et al., 2006). Given gender differences in challenges, motivators, and adaptations, such differences need to be taken into account when one investigates potential differences and similarities between managers and entrepreneurs (Korabik, 1990; Melero, 2011; Orhan \& Scott, 2001; Orser \& Dyke, 2009; Powell \& Eddleston, 2008). As there is a lack of comparative research between female management and entrepreneurship, this study was designed to fill gaps in the literature by investigating potential differences and similarities between women employed in organizations and self-employed women. More specifically, the focus was to study the extent to which entrepreneurship offered greater freedom from gender biases for women as well as the differences in gender roles and self-monitoring for women in management and women in entrepreneurship.

The research question asked whether there would be differences between female managers and female entrepreneurs regarding challenges, motivators, and adaptations to a

male-dominated business environment. Results showed that managers and entrepreneurs faced different challenges and had different motivators in each professional setting. Challenges mentioned by managers were managing different expectations, dealing with time constraints, facing gender stereotypes, and keeping a work-life balance. Entrepreneurs, however, did not mention fighting against gender stereotypes but rather struggling to keep a work-life balance, managing risk, and developing their businesses, 
which are common challenges among all entrepreneurs ("The Challenges for Entrepreneurship Today,” n.d.).

Regarding motivators, managers reported feeling passionate about their jobs, seeking to feel part of a team, and valuing compensation. Consistent with Orser and Dyke (2009) who found that “...an increase in the perceived importance of success defined as professional autonomy was associated with a decreased likelihood of being employed in a corporate management position for females only" (p. 342), the entrepreneurs in the present study entered this profession with a desire for greater freedom and autonomy.

Lastly, managers and entrepreneurs developed similar adaptations to the challenges they faced with one exception. They both changed their communication style according to audience and relied on their social support systems to deal with household responsibilities and on mentors for professional issues. However, only managers reported that they sometimes had to choose between their professional and personal goals; that is, they did not believe that they could advance in their careers while they were having children. Sacrificing a career over a family was only an issue for women working in organizations. According to Davey (2008), organizational politics are male-dominated and women struggle to navigate them, especially because such politics produce subtle barriers that are unanticipated by most women. One example of organizational politics harming women is illustrated by Hoobler, Wayne and Lemmon's (2009) study. They found that managers saw women as having greater family-work conflict than men, which translated into poorer evaluations of women and their career prospects. Accordingly, it is 
understandable that these types of gender biases are an issue for managers but not for entrepreneurs because entrepreneurs have more control over their professional advancement. Yet, entrepreneurs face other types of issues that managers do not. These include managing financial risk and being totally responsible for the success or failure of their companies. Such trade-off in responsibility, however, allows women to have more behavioral freedom, flexibility of schedule, and professional autonomy.

Hypothesis 1 stated that women employed in organizations would report a greater adoption of a masculine gender role than self-employed women. Results showed that there was no significant difference between employees and entrepreneurs on masculinity, thus, this hypothesis was not supported. This hypothesis was based on Brodsky's (1993) findings that managers scored much higher on masculinity than on femininity as well as on the argument that women's career advancement in organizations was constrained by conflicting role expectations (Orser \& Dyke, 2009). Results on gender roles in the present study are different from Brodsky's findings in that the women in this sample scored somewhat lower on masculinity. A reason for this difference might be due to a change in cultural zeitgeist. During the late 1980s and early 1990s, when Brodsky conducted her study, women were fervently fighting for their rights to equal pay and their mood was reflected in their choice of fashion, shoulder pads, and power dressing. Trying to appear equal to men likely primed women into adopting more masculine forms of presentation, thus, resulting in higher masculinity scores. However, the women in this study did not reject a feminine role as the women in Brodsky's study did. Changes such as increased female presence in business settings, weakened gender biases, and/or 
women's successful efforts in leadership might be promoting acceptance towards femininity displayed in a leadership role. However, as found in the interview responses, it is important to note that gender biases are still an issue in management.

Hypothesis 2 stated that female entrepreneurs would report a greater adoption of an androgynous gender role than female managers. Consistent with the hypothesis, the results of the $t$-test showed that entrepreneurs exhibited a significantly higher level of androgyny than managers. Brodsky (1993) found that entrepreneurs adopted an androgynous role more often than managers but failed to find that the difference was statistically significant. This study's results showed that entrepreneurs were indeed more androgynous than women in management. These results support the view that entrepreneurship offers women more freedom in the expression of femininity and is consistent with Gupta et al's (2009) finding that women defined entrepreneurship in androgynous terms. Unfortunately, results of the analysis using the median split to create four gender role categories showed that employees and entrepreneurs were not different on their gender roles. A closer look at Figure 1, however, shows that almost twice the entrepreneurs (36.1\%) were androgynous compared to the employees (21.6\%). Although there is support for the use of non-parametric as well as for parametric measures for androgyny (Blackman, 1985; Lenney, 1991; Williams, Leak, \& Millard, 1984), nonparametric tests such as a chi-square have been criticized for being less sensitive than parametric tests in rejecting a null hypothesis that is in fact false (Key, 1997). Therefore, the lack of significant results using the chi-square might be due to insensitivity of the test. 
Hypothesis 3 stated that women employed in organizations would score higher on self-monitoring than self-employed women because women in organizations face greater constraints. Results showed that entrepreneurs were more self-monitors than employees which was the opposite of what was expected. Nevertheless, all the women interviewed in this study reported changing their communication style (i.e., language, demeanor, and/or appearance) according to an audience, which is a sign of self-monitoring (i.e., observing and controlling one’s expressive behavior and presentation according to social cues) (Snyder, 1974). Perhaps the quantitative results diverged from the qualitative results because the women interviewed were all highly experienced and successful managers and entrepreneurs, whereas the women who took the survey were proportionally younger and at different stages in their careers. Another explanation is that entrepreneurs are more self-monitors than managers because they have to interact with clients who belong to different organizations with different cultures and expectations, whereas managers deal mostly with people from the same organization who adhere to similar norms and expectations.

\section{Strengths, Limitations, and Future Research}

The purpose of this study was to uncover potential differences and similarities between women in management and entrepreneurship. Two strengths of this study are the gathering of the qualitative data in addition to the survey data and the demographic diversity of the sample. Qualitative research is encouraged in the earlier stage of research on a subject such as the working conditions of female managers and entrepreneurs (Brodsky, 1993; Nichols-Casebolt \& Spakes, 1995). In this study, it was through 
interviews of female managers and entrepreneurs that differences and similarities between their challenges, motivators, and adaptations were clearly identified. Examples of differences are that gender biases have diminished but are still an issue for managers and that women enter entrepreneurship seeking greater freedom and autonomy whereas women enter organizations because of monetary rewards. Some similarities are that female managers and entrepreneurs change their communication styles to adapt to different audiences and rely on social support systems to keep a work-life balance. Regarding demographic diversity, the women in this study were more ethnically diverse than those in Brodsky's study (1993) and probably better represent the general population of women in the U.S.

Despite the several strengths of the study, it is not without limitations. One limitation of the present investigation is the relatively small sample size, which might have lessened statistical power and prevented further dissection of data (e.g., by industry). Sample characteristics were not ideal either; entrepreneurs were compared to women in organizations of which only $50 \%$ were actually managers. Future research should gather data from a larger sample of female managers and entrepreneurs in order to address these limitations and improve statistical analyses. The external validity of the results is limited by sample characteristics as well. The majority of the women in this study worked in IT (information technology) or related industry, which is a highly masculine arena. Women working in other industries may have different experiences that should be explored as well. Another limitation, not specific to this study, is the lack of consensus on measures 
of androgyny. Further research should address these limitations and strive to employ more comprehensive measures of gender roles and self-monitoring.

\section{Practical Implications of the Present Study}

This study helped expand the current knowledge on the challenges and adaptations of women in management and entrepreneurship and it has offered some support to the proposition that entrepreneurship offers more freedom from gender biases than management, which instead sustain gender stereotypes and hinders work-life balance. This new knowledge might help organizations target and eliminate obstacles to women's career advancement through their policies in order to retain them. For example, offering in-site child care and educating the workforce about gender biases could improve women's work experience and empower them to reach their professional goals. In fact, Vanderbroeck (2010) already suggested that, in order for organizations to benefit from a more diverse leadership, they must update their leadership development programs as well as their succession planning so as not to impair women’s professional efforts.

Another contribution of the study is the discovery of differences in selfmonitoring skills between women employed in organizations and self-employed women. Self-monitoring has been suggested as an adaptation tool for women in out-of-role positions (Anderson \& Thacker, 1985; Kanter, 1977; Korabik, 1990). Clearly female entrepreneurs have been taking advantage of this presentation skill and those who pursue such professional path should aspire to develop it as well. At the same time, knowledge obtained from this study might help women in deciding which career path to take, or in knowing what to expect from each and how to approach it. Lastly, the present findings 
challenge the existence of gender biases in entrepreneurship and the prescription of masculine gender roles for business women. Although gender biases still persist, their pervasiveness and impact vary across settings. In times of rapid changes, it becomes clear that researchers should constantly update their research in order to offer valuable information to professional women.

\section{Conclusion}

In the last few decades, women have increasingly defeated gender biases in the business world. However, their professional growth is faster in entrepreneurship than in management. Still, research has failed to uncover and explain potential differences and similarities between female managers and entrepreneurs and their professional experiences. The present study examined such differences and similarities and provided evidence that gender biases are still prevalent in organizations and that entrepreneurship offers a good alternative. Work-life balance is difficult to achieve for both groups, but it seems to be a bigger obstacle for women's advancement in management in organizations. Women have developed a set of adaptations to deal with such challenges including, but not limited to, relying on social support systems, adopting an androgynous gender role, and self-monitoring behaviors. Additional investigations are needed in order to better understand the complexity of women's professional work experiences and conditions. 


\section{References}

Ahl, H. (2006). Why research on women entrepreneurs needs new directions. Entrepreneurship Theory and Practice, 30, 595-621.

Anderson, L. R., \& Thacker, J. (1985). Self-monitoring and sex as related to assessment center ratings and job performance. Basic and Applied Social Psychology, 6, 345361.

Baumgartner, M. S., \& Schneider, D. E. (2010). Perceptions of women in management: A thematic analysis of razing the glass ceiling. Journal of Career Development, 3, 559-576.

Becker, J., Ayman, R., \& Korabik, K. (2002). Discrepancies in self-subordinates’ perceptions of leadership behaviors. Group \& Organization Management, 27, 226-244.

Bem, S. L. (1974). The measurement of psychological androgyny. Journal of Consulting and Clinical Psychology, 42, 155-162.

Berthold, N., \& Neumann, M. (2008). The motivation of entrepreneurs: Are employed managers and self-employed owner different? Intereconomics, 43, 236-244.

Blackman, S. (1985). Comparisons among methods of scoring androgyny continuously using computer-simulated data. Psychological Reports, 57, 151-154.

Bosak, J., \& Sczesny, S. (2011). Exploring the dynamics of incongruent beliefs about women and leaders. British Journal of Management, 22, 254-269.

Brodsky, M. A. (1993). Successful female corporate managers and entrepreneurs. Group \& Organization Management, 18, 366-378.

Bruni, A., Gherardi, S., \& Poggio, B. (2004). Entrepreneur-mentality, gender and the study of women entrepreneurs. Journal of Organizational Change Management, 17, 256-168.

Castilla, E. J., \& Benard, S, (2010). The paradox of meritocracy in organizations. Administrative Science Quarterly, 55, 543-576.

Catalyst (2010). 2010 Catalyst census: Fortune 500 women board directors. Retrieved July 29, 2011 from: http://catalyst.org/file/413/2010_us_census_women_board_directors_final.pdf 
Catalyst (2011). Women entrepreneurs. Retrieved July 29, 2011 from: http://catalyst.org/file/499/qt_women_entrepreneurs.pdf

Colley, A., Mulhern, G., Maltby, J., \& Wood, A. M. (2009). The short form BSRI: Instrumentality, expressiveness, and gender associations among a United Kingdom sample. Personality and Individual Differences, 46, 384-387.

Collins, C. J., Hanges, P. J., \& Locke, E. A. (2004). The relationship of achievement motivation to entrepreneurial behavior: a meta-analysis. Human Performance, 17, 95-117.

Daniel, T. A. (2004). The exodus of women from the corporate workplace to self-owned businesses. Employment Relations Today, 30, 55-61.

Davey, K. M. (2008). Women's accounts of organizational politics as a gendering process. Gender, Work and Organization, 15, 650-671.

De Bruin, A., Brush, C.G., \& Welter, F. (2006). Introduction to the special issue: towards building cumulative knowledge on women's entrepreneurship. Entrepreneurship Theory and Practice, 30, 585-593.

Dobbins, G. H., Long, W. S., Dedrick, E. J., \& Clemons, T. C. (1990). The role of selfmonitoring and gender on leader emergence: a laboratory and field study. Journal of Management, 16, 609-618.

Eagly, A. H., \& Carli, L. L. (2007). Women and the labyrinth of leadership. Harvard Business Review, 85(9), 63-72.

Eagly, A.H., \& Karau, S.J. (2002). Role congruity theory of prejudice toward female leaders. Psychological Review, 109, 573-598.

Gupta, V. K., Turban, D. B., Wasti, S. A., \& Sikdar, A. (2009). The role of gender stereotypes in perceptions of entrepreneurs and intentions to become an entrepreneur. Entrepreneurship Theory and Practice, 33, 397-417.

Heilman, M.E., \& Chen, J.J. (2003). Entrepreneurship as a solution: The allure of selfemployment for women and minorities. Human Resource Management Review, 13, 347-364.

Heilman, M.E., \& Okimoto, T.G. (2007). Why are women penalized for success at male tasks?: The implied communality deficit. Journal of Applied Psychology, 92, 8192. 
Hoobler, J. M., Wayne, S. J., \& Lemmon, G. (2009). Bosses’ perceptions of family-work conflict and women's promotability: glass ceiling effects. Academy of Management Journal, 52, 939-957.

Isaac, C., Griffin, L., \& Carnes, M. (2010). A qualitative study of faculty members' views of women chairs. Journal of Women's Health, 19, 533-546.

Kalin, R. (1979). Method for scoring androgyny as a continuous variable. Psychological Reports, 44, 1205-1206.

Kanter, R. M. (1977). Men and women of the corporation. New York: Basic Books.

Karau, S. J., \& Eagly, A. H. (1999). Invited reaction: Gender, social roles, and the emergence of leaders. Human Resource Development Quarterly, 10, 321-326.

Key, J. P. (1997). Research Design in Occupational Education. Retrieved May 30, 2012 from http://www.okstate.edu/ag/agedcm4h/academic/aged5980a/5980/newpage28.htm

Korabik, K. (1990). Androgyny and leadership style. Journal of Business Ethics, 9(4-5) 283-292.

Lenney, E. (1991). Measures of personality and social psychological attitudes. In P. J. Robinson, P. R. Phillip, \& L. S. Wrightsman (Eds.), Measures of social psychological attitudes (pp. 573-660). San Diego, CA, USA: Academic Press

Lennox, R. D., \& Wolfe, R. N. (1984). Revision of the self-monitoring scale. Journal of Personality and Social Psychology, 46, 1349-1364.

Lewis, P. (2006). The quest for invisibility: Female entrepreneurs and the masculine norm of entrepreneurship. Gender, Work, and Organization, 13, 453-469.

Melero, E. (2011). Are workplaces with many women in management run differently? Journal of Business Research, 64, 385-393.

Nichols-Casebolt, A., \& Spakes, P. (1995). Policy research and the voices of women. Social Work Research, 19(1), 49-55.

Orhan, M., \& Scott, D. (2001). Why women enter into entrepreneurship: An explanatory model. Women in Management Review, 16, 232-243.

Orser, B., \& Dyke, L. (2009). The influence of gender and occupational-role on entrepreneurs' and corporate managers' success criteria. Journal of Small Business and Entrepreneurship, 22, 327-354. 
Powell, G. H., \& Eddleston, K. A. (2008). The paradox of the contented female business owner. Journal of Vocational Behavior, 73, 24-36.

Riordan, C. A., Gross, T., \& Maloney, C. C. (1994). Self-monitoring, gender, and the personal consequences of impression management. The American Behavioral Scientist, 37, 715-725.

Sczesny, S., Spreemann, S., \& Stahlberg, D. (2006). Masculine = competent? Physical appearance and sex as sources of gender-stereotypic attributions. Swiss Journal of Psychology, 65(1), 15-23.

Snyder, M. (1974). Self-monitoring of expressive behavior. Journal of Personality and Social Psychology, 30, 526-537.

Stewart, W. H., \& Roth, P. L. (2007). A meta-analysis of achievement motivation differences between entrepreneurs and managers. Journal of Small Business Management, 45, 401-421.

The Challenges for Entrepreneurship Today (n.d.). In Small Business Notes. Retrieved May 30, 2012 from http://www.smallbusinessnotes.com/starting-a-business/thechallenges-for-entrepreneurship-today.html

U.S. Bureau of Labor Statistics (2009). Women and employment by industry. Retrieved September 23, 2011 from: http://www.bls.gov/opub/ted/2009/jan/wk1/art03.htm

U.S. Bureau of Labor Statistics (2010). Women in the labor force: a databook (Report No. 1026). Retrieved July 29, 2011 from: http://www.bls.gov/cps/wlf-intro2010.pdf

Vanderbroeck, P. (2010). The traps that keep women from reaching the top and how to avoid them. Journal of Management Development, 29, 764-770.

Williams, D., Leak, G., \& Millard, R. (1984). Relationship between androgyny and selfmonitoring. Psychological Reports, 55, 197-198.

Winn, J. (2004). Entrepreneurship: Not an easy path to top management for women. Women in Management Review, 19, 143-153. 